\title{
A proposed history of permafrost development in
} Labrador-Ungava

\section{L'évolution du pergélisol au Labrador-Ungava : une hypothèse} historique

\section{Eine angenommene Geschichte der Dauerfrostentwicklung in Labrador-Ungava}

\author{
Jack D. Ives
}

Volume 33, numéro 3-4, 1979

URI : https://id.erudit.org/iderudit/1000360ar

DOI : https://doi.org/10.7202/1000360ar

\section{Aller au sommaire du numéro}

\section{Éditeur(s)}

Les Presses de l'Université de Montréal

\section{ISSN}

0705-7199 (imprimé)

1492-143X (numérique)

\section{Découvrir la revue}

\section{Citer cet article}

Ives, J. D. (1979). A proposed history of permafrost development in Labrador-Ungava. Géographie physique et Quaternaire, 33(3-4), 233-244. https://doi.org/10.7202/1000360ar

\section{Résumé de l'article}

L'évolution du pergélisol au Labrador-Ungava : une hypothèse historique. Dans cet article, on retrace d'abord l'évolution récente de la cartographie de cette région, puis on tente de vérifier l'exactitude des dernières cartes produites. On discute ensuite des relations entre la température du sol et les diverses caractéristiques du milieu. À partir de ces prémisses, on élabore une hypothèse de l'évolution du pergélisol qui repose sur deux observations : 1) la plus grande partie du territoire du Labrador-Ungava est occupée par un pergélisol généralement en équilibre avec les conditions actuelles; 2) les zones de pergélisol relique sont nombreuses dans la partie méridionale de la péninsule. On croit donc qu'après la fonte du dernier inlandsis, le pergélisol a pu occuper de grands espaces avant la migration d'espèces arboréennes vers le nord. Puis les conditions thermiques du sol se sont modifiés à mesure que le couvert forestier s'installait. Ces changements ne sont pas uniquement le résultat direct de l'afforestation, mais aussi de la présence d'un épais couvert nival en forêt, là où la toundra était autrefois balayée par le vent. Le processus de dégradation du pergélisol a été d'autant plus actif que les conditions ressemblaient à celles qui prévalent aujourd'hui. Les lambeaux reliques résultent de ce processus. Cette hypothèse s'appuie sur les résultats de recherches en palynologie et en histoire de la végétation. Ceux-ci attestent que la toundra a occupé le territoire pendant au moins 1000 à 2000 ans après le retrait de l'inlandsis et avant l'afforestation.
Tous droits réservés @ Les Presses de l’Université de Montréal, 1979
Ce document est protégé par la loi sur le droit d'auteur. L'utilisation des services d’Érudit (y compris la reproduction) est assujettie à sa politique d'utilisation que vous pouvez consulter en ligne.

https://apropos.erudit.org/fr/usagers/politique-dutilisation/ 


\section{A PROPOSED HISTORY OF PERMAFROST DEVELOPMENT IN LABRADOR-UNGAVA}

Jack D. IVES, Institute of Arctic and Alpine Research, and Department of Geography, University of Colorado, Boulder, Colorado 80309, U.S.A.

ABSTRACT The recent history of mapping permafrost distribution in LabradorUngava is reviewed and an attempt is made to assess the accuracy of the most recent maps. Relationships between ground temperature and other environmental conditions are then discussed These two introductory sections provide the basis for the main objective of the paper. A hypothesis of permafrost development is elaborated and rests upon two considerations: (1) that much of Labrador-Ungava is underlain by permafrost which is in approximate equilibrium with present-day conditions and that its distribution is largely controlled by vegetation cover rather than regional variations in climate, and (2) that patches of relic permafrost have been found widely throughout the southern section of the peninsula. It is proposed that, following disintegration and melt of the last ice sheet, permafrost developed over wide areas before tree species were able to migrate northwards. As the forest cover-types began to occupy areas comparable to those so occupied today ground thermal characteristics changed. This was caused not only by the direct effects of forest invasion but by the impact of the forest on the winter snow cover. As conditions more nearly approached those prevailing today, degradation of permafrost set in and the present relic patches are all that remains of this process. The hypothesis is supported by recent progress in palynological and vegetational history studies. These demonstrate that a tundra phase existed for 1000 to 2000 or more years between the time of ice sheet disappearance and establishment of the forest cover.
RÉSUMÉ L'évolution du pergélisol au Labrador-Ungava: une hypothèse historique. Dans cet article, on retrace d'abord l'évolution récente de la cartographie de cette région, puis on tente de vérifier l'exactitude des dernières cartes produites. On discute ensuite des relations entre la température du sol et les diverses caractéristiques du milieu. A partir de ces prémisses, on élabore une hypothèse de l'évolution du pergélisol qui repose sur deux observations: 1) la plus grande partie du territoire du Labrador-Ungava est occupée par un pergélisol généralement en équilibre avec les conditions actuelles; 2) les zones de pergélisol relique sont nombreuses dans la partie méridionale de la péninsule. On croit donc qu'après la fonte du dernier inlandsis, le pergélisol a pu occuper de grands espaces avant la migration d'espèces arboréennes vers le nord. Puis les conditions thermiques du sol se sont modifiés à mesure que le couvert forestier s'installait. Ces changements ne sont pas uniquement le résultat direct de l'afforestation, mais aussi de la présence d'un épais couvert nival en forêt, là où la toundra était autrefois balayée par le vent. Le processus de dégradation du pergélisol a été d'autant plus actif que les conditions ressemblaient à celles qui prévalent aujourd'hui. Les lambeaux reliques résultent de ce processus. Cette hypothèse s'appuie sur les résultats de recherches en palynologie et en histoire de la végétation. Ceux-ci attestent que la toundra a occupé le territoire pendant au moins 1000 à 2000 ans après le retrait de l'inlandsis et avant l'afforestation.
ZUSAMMENFASSUNG Eine angenommene Geschichte der Dauerfrostentwicklung in Labrador-Ungava. Die unmittelbare Geschichte der Darstellung der Dauerfrostverteilung in Labrador-Ungava, wird nachgeprüft und man macht einen Versuch, die Präzision der neuesten Karten einzuschätzen. Die Beziehungen zwischen der Bodentemperatur und anderen Umweltsverhältnissen werden anschliessend besprochen. Diese beiden einleitenden Teile bilden die Grundlage für das Hauptziel dieses Artikels. Eine Hypothese der Dauerfrostentwicklung wird ausgearbeitet und beruht auf zwei Überlegungen: 1) Dass fast ganz Labrador-Ungava von Dauerfrost unterlegt ist. welcher in ungefährem Gleichgewicht mit den heutigen Verhältnissen ist, und dass seine Verteilung grösstenteils durch die Vegetationsdecke vielmehr als durch regionale Klimavariationen bestimmt wird. 2) Dass in den südlichen teilen der Halbinsel heufig alte Dauerfrostflecken gefunden werden. Es wird angenommen, dass sich Dauerfrost als Folge des Schmelzens der Eisdecke entwickelte, ehe Bäume sich nordwärts ansiedeln konnten. Der thermale Bodenkarakter hatte sich verändert, ehe die Walddeçke ihre, der heutigen vergleichbare. Ausdehnung einnahm. Dies war nicht nur auf die unmittelbaren Folgen der Bewaldung zurückzuführen, sondern auch auf den Einfluss des Waldes auf die Schneedecke im Winter. Als die Verhältnisse sich den heutigen näherten, setzte eine Degradierung des Dauerfrostes ein und die heutigen alten Flecken sind alles was von diesem Vorgang übrig bleibt. Die Hypothese wird von neuzeitigen Erkenntnissen in polinologischer und pflanzlicher Geschichte unterstützt. Diese bezeugen, dass es vor 1000-2000 Jahren, zwischen der Zeit des Verschwindens der Eisdecke und der Bewaldung eine Tundraphase gegeben hat. 


\section{INTRODUCTION}

It has been assumed for many years that significant areas of Labrador-Ungava are underlain by permafrost (NIKIFOROFF, 1928). There is even an intriguing literary reference: "She did feel the peculiar, withering coldness under it all, like the soil of Labrador, which has gay little flowers on its surface, and a foot down is frozen." So spoke Lady Chatterly of Lady Bennerly (D. H. Lawrence, 1929, Paris). But it was only with the development of iron mining at Schefferville and the establishment of the McGill Sub-Arctic Research Laboratory in 1954 that any real understanding of permafrost characteristics and distribution began to emerge. Even today any map of permafrost distribution for the peninsula depends heavily upon widespread extrapolation of data and understanding of environmental relationships from the small area around Schefferville, although new work in the Leaf Bay area is rapidly adding to this (GRAY and PILON, 1976). Further, the degree of success of any attempt to provide a history of permafrost development will depend very much upon the reliability of maps of present permafrost distribution. Thus the first part of this paper will discuss the history of permafrost mapping and analyze the accuracy of the most recent maps. The second part will review the relationships between ground temperature and various environmental conditions, while the final part will be devoted to elaboration of a hypothesis of permafrost development.

\section{MAPPING PERMAFROST IN LABRADOR-UNGAVA}

Aside from the early and very sketchy attempts to portray permafrost distribution in Labrador-Ungava (cf. NIKIFOROFF, 1928) the first substantial progress was made by J. L. JENNESS (1949). He provided a provisional outline of permafrost distribution as part of a study embracing the whole of Canada. He used two categories of individual site reporting: "continuous permafrost reported underlying the entire area," and "patches of permafrost, generally under muskeg only...," and a line depicting the "tentative southern limit of continuous permafrost." For the two site categories there are only four points of actual field observation representing the entire peninsula, and the single point in the first category (Chimo) would appear inaccurate from more recent accounts (see especially GRAY and PILON, 1976). Nevertheless, coupled with an appraisal of mean annual air isotherms, themselves highly tentative, his "southern limit" line is remarkably accurate for its time and his entire essay an outstanding achievement. It was not until 1960, however, that a systematic attempt was made to apply to Canada the Soviet reconnaissance mapping experience that was based upon an understanding of approximate relationships between mean annual air temperatures and mean annual ground temperatures (BROWN, 1960). BLACK (1954) had previously produced a permafrost map of the Northern Hemisphere using similar approximations. He identified three permafrost zones: continuous, discontinuous, and sporadic, and while his southern limit of sporadic permafrost is remarkably consistent with present-day knowledge, his southern limit of continuous permafrost, at least for Canada, is much too far north. BROWN's map (1960, fig. 5) became the progenitor of a series of maps that have been successively refined, down to the most up-todate version reproduced elsewhere in this volume (BROWN, 1979). The use of mean annual air isotherms as the primary guideline is retained as the basis of this map, although the sophistication of detail has been progressively achieved over the years as it proved possible to incorporate more and more detail from actual field observations (BROWN, 1969, 1975) and ground temperature measurements (NICHOLSON, 1975, 1976, 1979). Brown's permafrost divisions eliminate the "sporadic zone" of BLACK (1954) and in effect, depend upon two subdivisions of a "discontinuous zone," although Ives has argued that this has become a matter of semantics (IVES, 1973, 1974).

Between 1960 and 1978 the evolution of permafrost mapping in Labrador-Ungava proceeded along two distinct lines. The first was the use of air temperature/ ground temperature empirical relations, supplemented by scattered ground observations as discussed above and applied by Brown; this is the only rational way to proceed given the requirement that subcontinental areas the size of Canada are to be mapped at a reconnaissance level. Nevertheless, Brown has paid special attention to the need for extensive field investigations to obtain information for the mapping of the southernmost limit (BROWN, 1965, 1967, 1968, 1975), and as a consequence, the southern limit is well defined.

The second line of approach derives from the work undertaken jointly by the McGill Sub-Arctic Research Laboratory and the Iron Ore Company of Canada with extensive assistance from the Division of Building Research, National Research Council. This approach has utilized the opportunities presented by the largescale mining activities and attendant deep drilling for installation of temperature sensing elements to depths exceeding $100 \mathrm{~m}$. In addition, there has been extensive data collection on snow depths, period of snow cover, vegetation type, topography, air temperatures and other factors. The first systematic ground temperature measurements were undertaken by Bonnlander in 1957 (BONNLANDER and MAJOR-MAROTHY, 1964). While this immediately resulted in the realization that permafrost was quite widespread and in places approached 
$100 \mathrm{~m}$ in thickness, the vertical spacing of the thermocouples was too great to provide information on the thickness and temperature conditions of the active layer; thus uncertainty remained about whether the permafrost was in equilibrium with present-day climate because it was not known whether or not the active layer froze all the way down to the permafrost table. Following this initial work a systematic program of ground and air temperature measurements, together with study of snow and vegetation characteristics, was established as a joint McGill University - Iron Ore Company effort (IVES, 1961, 1962) and was subsequently greatly expanded by ANNERSTEN (1964) and especially by NICHOLSON $(1975,1976,1979)$. This work produced a number of broad conclusions vital to any attempt to explain the history of permafrost development in Labrador-Ungava: (1) that much of the permafrost in the Schefferville area is in equilibrium with present-day climate; (2) that the distribution of this "modern" permafrost is closely correlated with terrain factors; principally snow cover duration and thickness, vegetation, and topography; and (3) that relic ${ }^{1}$ patches of permafrost occur in widely scattered localities throughout southern Labrador-Ungava. In particular, the initial general assumptions of IVES (1960a, 1961, 1962) that permafrost is in equilibrium with present-day environmental conditions and can be expected to occur in windswept areas above treeline as far south as the Laurentide Escarpment and into Haute Gaspésie and

1. The terms "relic" and "contemporary" permafrost are of vital importance in the context of this paper. "Contemporary permafrost" implies the occurrence of perennially frozen ground that is compatible with existing climatic and terrain conditions. Thus, in most years, but not necessarily every year, the active layer will refreeze entirely each winter so that no talik remains above the permafrost table. This does not imply that thermal gradients to greater depths will not show anomalies that can be ascribed to recent climatic change. In contrast, "relic permafrost" is not compatible with present climatic and terrain conditions. Identification of relic permafrost is best achieved when its uppermost surface is separated by an extensive and thick talik from the deepest seasonal frost. This condition has been detected during mining operations in the Schefferville and Labrador City vicinities and "pods" of perennially frozen ground have been shown to occur with upper surfaces as much as 20 to $30 \mathrm{~m}$ below the zone of seasonal frost penetrations (H. E. Neal, pers. comm., 1958). In such cases it can be assumed that the origin of such deep-seated blocks of permafrost relates to a completely different combination of climate and/or terrain conditions than those prevailing today. It should be anticipated, however, that with increasing surface elevation and reduced vegetation cover, there should be a gradual transition such that within the treeline ecotone differentiation between relic and contemporary permafrost will become progressively more difficult. Finally, it follows from this argument that relic permafrost wil only be discovered by chance excavation, usually relating to large scale engineering, mining, or construction activities.
New England have been substantiated by GRAY and BROWN (1979), NICHOLSON $(1976,1979)$ and BROWN $(1975,1979)$. These initial assumptions led to the first detailed map of "predicted permafrost" occurrence for Labrador-Ungava (IVES, 1962, 1974) based upon a combination of field data from the Schefferville area and HARE's map of vegetation cover (1959). Subsequent adaptations of this map, notably by BROWN (1975) and NICHOLSON $(1976,1979)$, provide the basis for discussion of the history of permafrost development. Finally, Brown's latest map combines both lines of approach and becomes the most authentic map of permafrost distribution for the southern half of the peninsula (BROWN, 1979).

A few comments on the accuracy of the latest maps are necessary, therefore, before proceeding to a discussion of the history of permafrost development in the peninsula. Brown's extensive field reconnaissance (BROWN, 1975) permits the assumption that the southern limit of scattered patches of permafrost above treeline is quite accurately presented. The assumption is justified because the southern limit is based upon both widespread probing and consideration of the theoretical relationships amongst vegetation, snow cover, topography, and ground temperature derived from precise measurements in the Schefferville vicinity. The southern delimitation of widespread permafrost by BROWN $(1975,1979)$ is well authenticated for the Schefferville area, but elsewhere is dependent upon the same type of extrapolation that relates snow cover to ground temperature. In this respect, Brown's map is essentially identical to that produced by IVES (1962) and assumes that "contemporary permafrost" will occur whenever the land surface is more or less blown free of snow for much of the winter. BROWN $(1975,1979)$, however, has provided additional information on permafrost occurrence in nearby peatlands below treeline. Nevertheless, Hare's cover types of "bare rock" and "lichen health" become equated with "contemporary permafrost," excepting the peatland situation, and where these cover types are extensive, as through much of the northern half of the peninsula, they essentially equate with the zone of continuous permafrost. The physical character of the peninsula, however, when considered in conjunction with this line of reasoning, together with an absence of widespread ground temperature data, makes it difficult to produce a general map showing the three traditional permafrost zones (either: continuous, discontinuous-widespread, discontinuous-scattered, or continuous, discontinuous, and sporadic). What we face in Labrador-Ungava is the merging of the traditional permafrost zone concept with actual occurrences related to altitude and treeline. Thus, the alpine altitudinal belt concept must be superimposed upon the latitudinal zone concept. Nevertheless, the distribution, as shown 
on BROWN's maps $(1975,1979)$ is accurate enough to serve as a basis for the discussion of the history of permafrost development, even though there is scant knowledge of permafrost thickness beyond the mining areas of Asbestos Hill, Schefferville, and Labrador City. More recently, however, temperature data have been obtained from three deep holes at an exploration site $70 \mathrm{~km}$ south of Leaf Bay (GRAY and PILON, 1976). Here permafrost is several hundred meters thick and probably continuous throughout the surrounding area. Also preliminary analysis of data from the James Bay region indicates the occurrence of discontinuous permafrost north of Poste de-la-Baleine (BOTTRON, GILBERT, LOCAT and GRAY, 1979). Nevertheless, a major gap in knowledge concerns the lack of information on the possible occurrence of relic patches of permafrost. These are known to occur in the vicinity of Schefferville and Labrador City (IVES, 1962), and Churchill Falls (ANDREWS, 1961; CAPLAN, 1961), that is, wherever extensive excavations have been made in the south-central tracts of the peninsula. It must be assumed that other relic patches, yet to be discovered, do exist across this vast area, and such an assumption is critical to any initial evaluation of the history of permafrost development. Figure 1 is reproduced from a combination of BROWN (1979) and IVES (1962) to provide an overview of permafrost distribution for the entire peninsula.

\section{RELATIONSHIPS BETWEEN GROUND TEMPERATURE AND VARIOUS ENVIRONMENTAL CONDITIONS}

It has long been assumed that, south of the northern zone of continuous permafrost, as mean annual air temperatures more nearly approach $0^{\circ} \mathrm{Celsius,} \mathrm{varia-}$ tions in snow cover and other so-called secondary factors become increasingly important in determining whether ground temperatures will fall on the positive or negative side of the permafrost threshold. Thus surface cover type, wind speed and direction, snowfall amount, duration and time of fall and melt in relation to air temperatures, and topography and aspect, are all closely interrelated. Similarly, the geothermal flux, and the thermal properties of the subsurface material will affect the geothermal gradient and hence permafrost distribution. NICHOLSON $(1976,1979)$ has examined these aspects of permafrost distribution in the immediate vicinity of Schefferville in great detail. Here it is appropriate to follow his conclusion that "in general, using a variety of snow measures, the critical snow depth which will prevent the formation of permafrost seems to be a mean peak snow depth of about 75 to $80 \mathrm{~cm}$ " (NICHOLSON, 1979, p. 275). HAEBELI (1975, 1978), following extensive snow and ground temperature studies in the Alps, has demonstrated interesting relationships between ground surface temperatures beneath a snowpack and permafrost distribution. It would be useful to test these conclusions in LabradorUngava. The statement of NICHOLSON (1979), in a very general way, supports the earlier contention that, for much of the area that extends above treeline snow will be shallow or non-existent for much of the winter, whereas below the treeline, or south of the treeline, snow will accumulate to thicknesses exceeding Nicholson's critical limits of 75 to $80 \mathrm{~cm}$. It is also important to point out that this vital relationship between snow thickness, vegetation, topography, and ground temperature does not hold for the Canadian permafrost zones across the Districts of Keewatin and Mackenzie, nor in the Yukon Territory, simply because the climate is much more continental, with considerably less snowfall. In these areas, as is well known, the southern limit of permafrost extends up to several hundred kilometers south of the arctic treeline. This factor may well be important also in the low snow accumulation areas of the open lichen woodlands north of the main LabradorUngava snow belt, for instance, in the area of the Leaf and Larch Rivers (Gray, personal communication, 1978).

\section{HYPOTHESIS FOR PERMAFROST DEVELOPMENT IN LABRADOR-UNGAVA}

The existence of extensive areas underlain by permafrost that is in equilibrium with present-day climate can now be taken as an established fact. The known existence of relic permafrost below the treeline and in areas where snow accumulates to thicknesses much in excess of 75 to $80 \mathrm{~cm}$ demands an explanation. It can be assumed that this relic permafrost is the legacy from a period in the past when the climate was more conducive to the development of perennially frozen ground. More correctly, it should be related to a past period when the surface energy exchange was substantially different from that of today. This condition can be accounted for in two ways: either the climate was different - less snowfall, lower air temperatures, or a combination of both; or the vegetation was different - little or no tall vegetation, so that snow accumulation patterns were not the same as those prevailing today. And, of course, both of these could have occurred together. It could be assumed that absence of forest cover across the area between Schefferville, Churchill Falls, and Labrador City would itself be a reflection of previous, more severe climate, but this is not necessarily so. Absence of forest cover could be explained by assuming a rapid melting of the remnant Laurentide Ice Sheet between about 9000 and 6000 years ago (IVES, 1960b; BRYSON, et al. 1969; PREST, 1970) and a significant time-lag before the newly uncovered area was colonized by tree species migrating from the south and southwest. This latter consideration was originally discussed in out- 


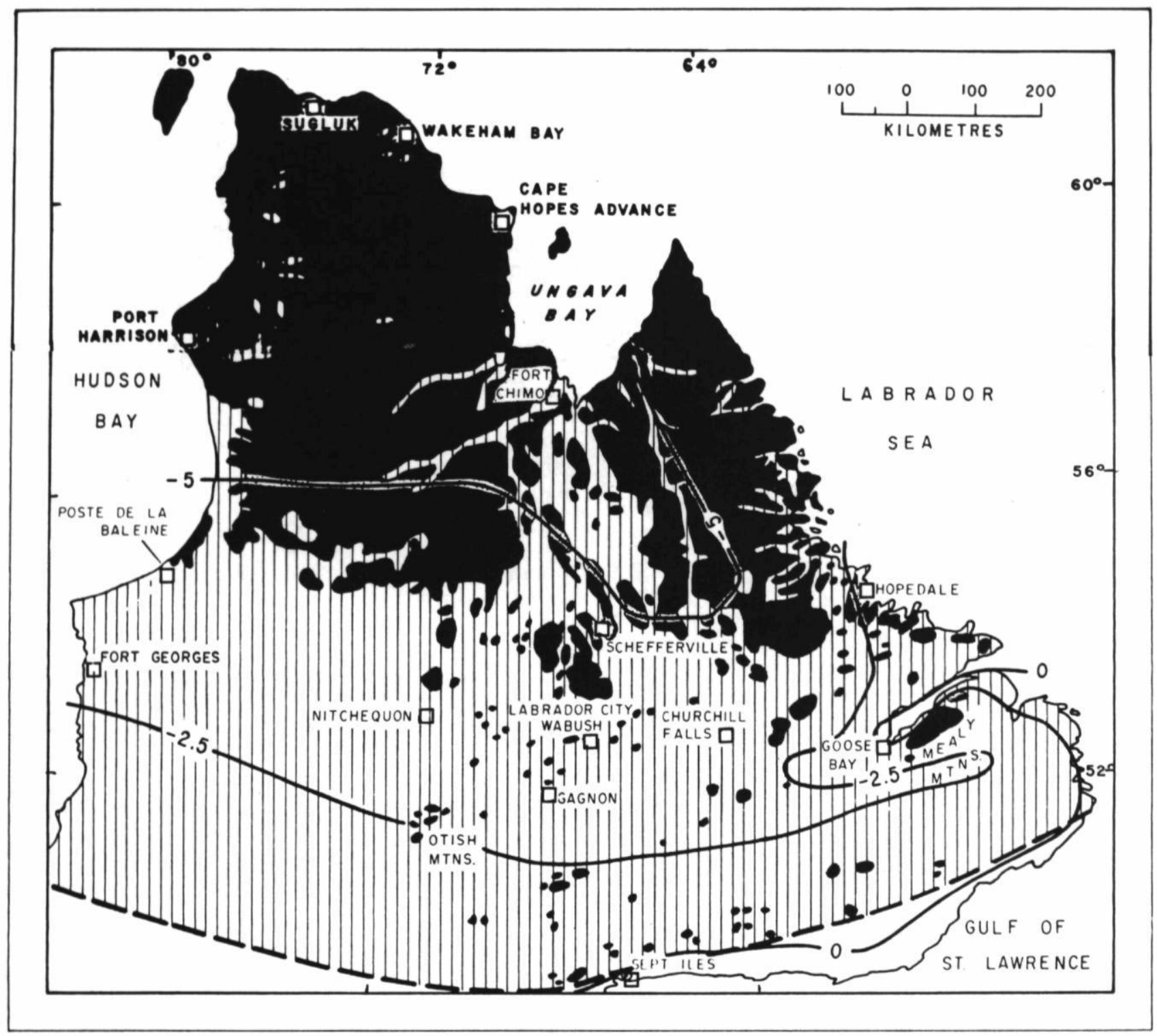

PREDICTED OCCURRENCE OF CONTEMPORARY PERMAFROST
FORMED AND MAINTAINED UNDER PRESENT CLIMATIC REGIME

III PERMAFROST ISLANDS IN PEATLANDS; AND PREDICTED OCCURRENCE OF RELIC PERMAFROST PATCHES FORMED UNDER PREVIOUS CLIMATIC REGIME

- SOUtherN limit OF PERMAFrost

MEAN ANNUAL AIR ISOTHERM, ${ }^{\circ} \mathrm{C}$

FIGURE 1. Permafrost distribution in Nouveau-Québec and Labrador (after BROWN, 1967, 1979; IVES, 1962).
La répartition du pergélisol au Nouveau-Québec et au Labrador (d'après BROWN, 1967, 1979; IVES, 1962). 
line form by IVES (1962). At that time little was known about the 'absolute' chronology of Laurentide ice disintegration and melt, and practically nothing was known concerning the history of vegetation development over the last 6000 to 10,000 years. With rapid increase in knowledge in these two related fields of inquiry over the last five years or so it seems opportune to develop the hypothesis in greater detail, at least in the hope that it will serve as a target for criticism and further field investigation.

The hypothesis rests upon a number of assumptions, most of which can be tested, at least in part. The first is that the entire peninsula with minor exceptions along the Atlantic coast (IVES, 1978) was mantled by a thick ice sheet during much of the last 100,000 years or so, and especially during the maximum of the last glaciation about 18,000 BP (Fig. 2). It would follow from this assumption, combined with the latitudinal position of the peninsula, and reconstructions of the climate of 18,000 BP (CLIMAP, 1976; LAMB and WOODROFFE, 1970; WILLIAMS et al., 1974) that the ice sheet basal temperatures were at the pressure melting point over wide areas. The basal temperature reconstructions of SUGDEN $(1977,1978)$ refer to an assumed maximum, pre-Wisconsin condition of the Laurentide Ice Sheet and are therefore not relevant to the present discussion. Thus, subglacial permafrost would be either nonexistent, of small extent, or else very deep-seated and related to a much earlier cold period ${ }^{2}$. This particular line of reasoning is difficult to quantify, although the extant distribution of "contemporary" permafrost appears to be so closely related to the present cover types of the peninsula that it may be assumed to have developed in lateglacial and post-glacial times.

A second assumption is that, following the late Last Glacial maximum, progressive disappearance of the Labradorean sector of the Laurentide Ice Sheet was, with minor exceptions, concentric inwards toward a centre with a radius of $300 \mathrm{~km}$ about Kivivic Lake, situated some $40 \mathrm{~km}$ northnorthwest of Schefferville (IVES, 1960b; BRYSON et al., 1969; PREST, 1970; IVES et al., 1976). Further to this it is assumed that the remnant ice mass persisted until well into the Holocene. Best guesses indicate that final disappearance occurred about 6000 BP (GRAYSON, 1956; PREST, 1970; IVES et al., 1976). While the ages of the Naskaupi glacial lake shorelines in the George River Basin (IVES et al., 1976;

2. Even at basal ice sheet temperatures of, for instance, $-0.5^{\circ} \mathrm{C}$, permafrost could develop during glacial maxima to thicknesses of 50 to $100 \mathrm{~m}$ over extensive areas. This could persist to the present given continued severe climatic conditions. Nevertheless, subglacial meltwater patterns produced during the deglacierization phase indicate that basal temperatures, at least during that period, were at the pressuremelting point (IVES, $1960 \mathrm{c}$ ).
MCANDREWS and SAMSON, 1977; SHORT and NICHOLS, 1977) are becoming increasingly well defined, the date of final disappearance in the area north of Schefferville requires more extensive study. Even after more than two decades of investigation the dating of this crucial event hangs upon a single radiocarbon date produced by GRAYSON (1956), itself only the basis for extrapolation. Other dates obtained by Grayson from $250 \mathrm{~km}$ south and $250 \mathrm{~km}$ north of his Greenbush site (Kivivic Lake vicinity) and much more extensive work by MORRISON $(1966,1970)$ in the Churchill Falls area, do not provide much more definitive knowledge.

In 1975 Ives and Nichols (unpublished) resampled Grayson's Greenbush Lake bog and also obtained lake sediment cores from Boundary Lake $3 \mathrm{~km}$ north of Kivivic Lake. A date of $3830 \pm 60 \mathrm{BP}$ (DIC-884) from the bottom section of the Greenbush core (compared to $5300 \pm 800 \mathrm{BP} ;$ GRAYSON, 1956) together with examination of the material collected, serves only to indicate the unreliable nature of ${ }^{14} \mathrm{C}$ dates from this site. It was clear from peat stratigraphic analyses that an unconformity at the sediment base debarred the peat from providing anything other than a date for initiation of peat growth long after deglaciation. Furthermore, the first radiocarbon assays of the Boundary Lake sediment cores obtained by Ives and Nichols in 1975 produced a date of $16,330 \pm 330 \mathrm{BP}(\mathrm{QL}-1214)$ from the bottomost $10 \mathrm{~cm}$ (absolute depth 284-294 cm) and one of $9980 \pm$ $140 \mathrm{BP}$ (QL-1214B) from the 264 to $284 \mathrm{~cm}$ level (personal communication, Minze Stuiver, 1978). An additional date from the 253 to $263 \mathrm{~cm}$ level of an adjacent core immediately above a hard base yielded an age of $10,700 \pm 540 \mathrm{BP}(\mathrm{GX}-5520)$.

For the purpose of this paper, therefore, it is necessary, at least until more detailed work is completed, to retain the pre-existing extrapolated chronology of final Laurentide Ice Sheet disappearance from the geographic centre of Labrador-Ungava as shown in Figure 3 (defined here as a roughly circular area centered on Kivivic Lake and with a radius of $300 \mathrm{~km}$ - approximately Kivivic Lake to the vicinity of Churchill Falls).

The third set of assumptions centres on the theme that, following the final disappearance of the remnant Laurentide ice, a significant time-lag occurred before the approximate present boundaries of the open lichen woodland and northern Boreal Forest were attained. Early palynological studies in the general area of Labrador-Ungava, for instance, those by WENNER (1947) and POTZGER (1953) were not very helpful, primarily because they lacked absolute dates and Potzger only counted tree pollen. The first work in the geographical centre with ${ }^{14} \mathrm{C}$ dating control was that of GRAYSON (1956) who recognized three pollen zones. The first represented a short tundra interval succession- 


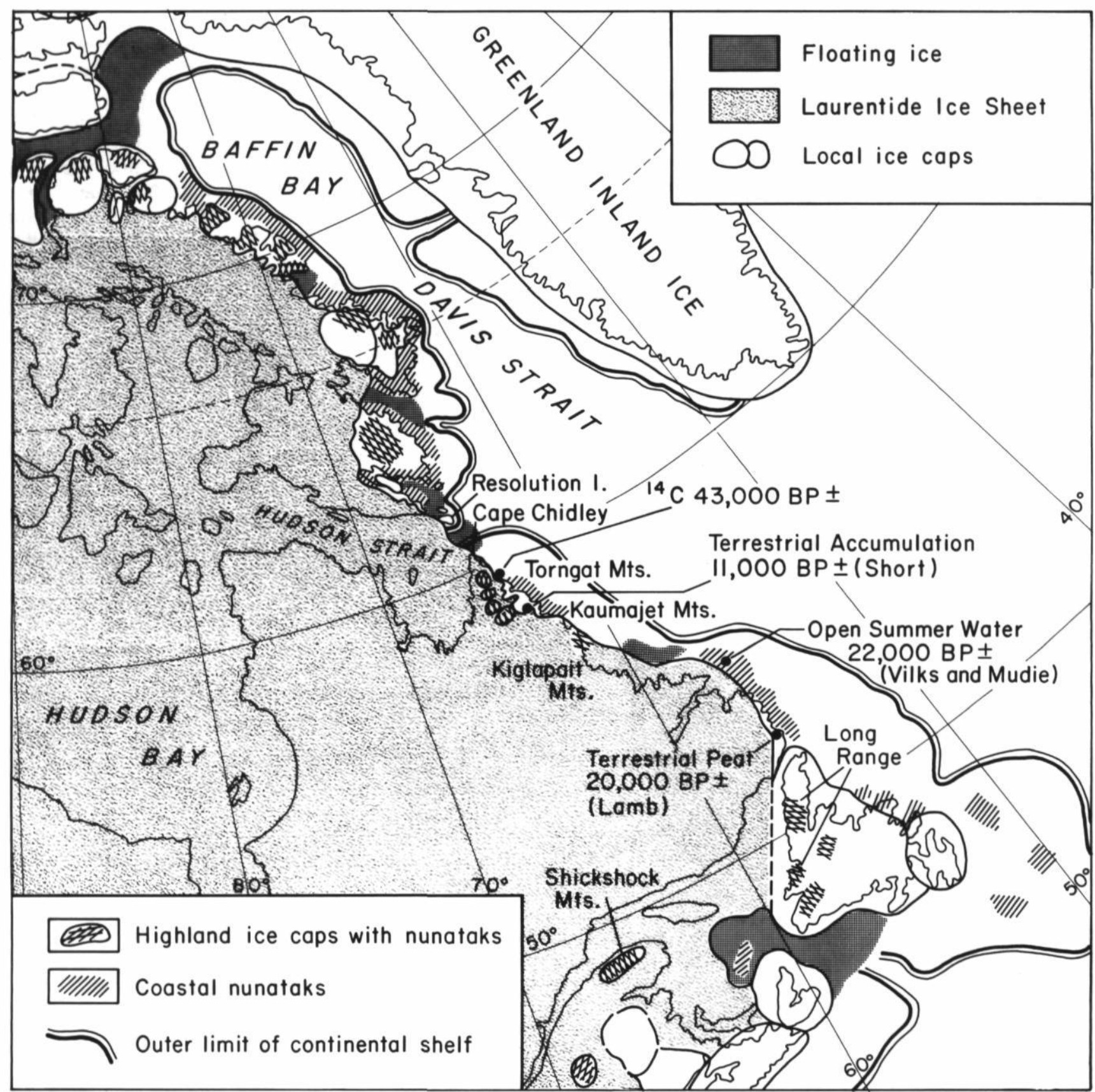

FIGURE 2. Maximum extent of Last Glaciation Ice (from IVES, 1978).

al to a second episode characterized by birch-alder, while a third zone represented a boreal woodland dominated by spruce and which occurred over the last 4000 to 5000 years. Dating control of Grayson's pollen diagrams was minimal.

Thereafter a long period of inactivity followed although in the late 1960's and early 1970's work in
Extension maximale de la dernière glaciation (d'après IVES, 1978).

southeastern Québec and northern New England began to show that a tundra phase followed immediately on the heels of final ice sheet disappearance (TERASMAE and LASALLE, 1968; RICHARD, 1973, 1975a and b; DAVIS et al., 1975; MOTT, 1977. Subsequently, knowledge of the late and postglacial history of vegetation northeast of Québec City expanded rapidly, and the succession showed first a periglacial desert followed by a 


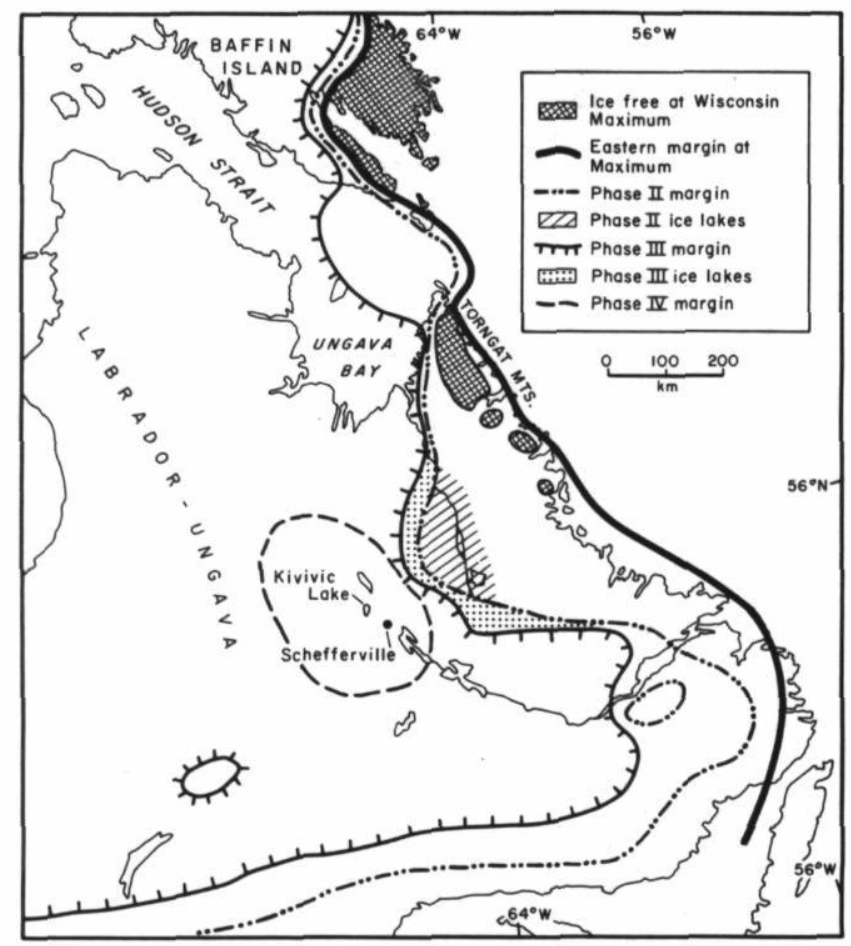

FIGURE 3. Schematic retreat phases of the Laurentide Ice Sheet in Labrador-Ungava and southern Baffin Island from its "Classical Wisconsin" maximum to about 6000 BP. The maximum position along much of the Labrador coast possibly dates from between 14000 and $18000 \mathrm{BP}$, but may be as recent as $8500 \mathrm{BP}$ in Baffin Island. Phases II and III probably fall between 8500 and 7000 BP (from IVES, NICHOLS and SHORT, 1976).

Les différentes phases du retrait de l'inlandsis laurentidien au Labrador-Ungava et au sud de l'île de Baffin à partir de son extension maximale connue jusqu'à 6000 ans BP. Le tracé au large de la côte du Labrador date probablement de 14000 à 18000 ans BP, tandis que celui situé au large de l'île de Baffin peut aussi bien dater de 8500 ans BP. Les phases II et III se situent probablement entre 8500 et 7000 ans BP (d'après IVES, NICHOLS et SHORT, 1976).

tundra phase prior to the establishment of forest vegetation (RICHARD, 1977a, 1977b). MORRISON (1970), working in the Churchill Falls area of Labrador, sampled ten peat bogs and identified six pollen zones, the earliest of which (zones 6 through 3) were interpreted as brief successional episodes: tundra through alder-birch shrub to spruce forest, spanning about 500 years between 5700 and 5200 BP (MORRISON, 1966, 1970). JORDAN (1975) and McANDREWS (1976a and 1976b) working still further east and north extended the concept of an immediate postglacial tundra phase. However, the most completely dated pollen diagrams for the northeast derive from the preliminary analyses of SHORT and NICHOLS (1977). They produced six "relative" and "absolute" diagrams from the northeastern quadrant of the peninsula, which indicated that a prolonged tundra period followed final ice sheet disappearance. Minimal deglaciation dates for the sites varied between more than 10,000 BP near the Atlantic coast to about 7000 BP in the George River basin, although some ${ }^{14} \mathrm{C}$ inversions complicate the interpretation. Nevertheless, all showed a substantial tundra period, varying in length between 4000 and 2000 years. Four sites registered a clear transition from grass-heath tundra to willow-birch-alder to shrub tundra at similar times (about 6500 radiocarbon years ago) with a marked increase in organic sedimentation rates. Finally, shrub tundra appears to have given way to open woodland at these sites about 4500 years ago, followed by woodland retreat indicating more severe climatic conditions after 3000 BP. McANDREWS (1976a, 1976b) and McANDREWS and SAMSON (1977) have also contributed substantially to this recent increase in knowledge of postglacial vegetation succession in NouveauQuébec.

For the purpose of discussing permafrost development, the palynological studies are of great significance, especially in that they provide increasing evidence for the existence of an important tundra interval across a wide area. Nevertheless, direct comparison between some of the sites, for instance, between those of SHORT and NICHOLS (1977) and those of MORRISON (1966, 1970 ), is difficult because of the contrast in their present vegetation characteristics. At issue here is whether or not the conclusion of Short and Nichols, that a long tundra period occurred (2000 years or more), can be applied to the area between Churchill Falls and Labrador City (presently within the northern limits of the Boreal Forest), as opposed to the short period of some 500 years proposed by Morrison. This problem will ultimately be resolved through the current spurt of palynological research in Labrador-Ungava (Richard, personal communication, 1978; Nichols, personal communication, 1978). Nevertheless, it will be assumed here that enough is now known concerning immigration of tree species following deglaciation to strengthen the hypothesis that a significant period of treelessness occurred. From this it can be inferred that very different snow cover conditions from present occurred which enabled permafrost to develop. Subsequent invasion of the area south of Schefferville by Boreal Forest and open lichen woodland associations produced a major change in the pattern of winter snow accumulation, and surface energy exchange in general, for widespread permafrost degradation to begin, at least several thousand years ago. Figure 4 is reproduced from SHORT and NICHOLS (1977) to illustrate the basis for this supposition. Thus the hypothesis of permafrost development in Labrador-Ungava is not dependent upon climatic change. That significant changes in 


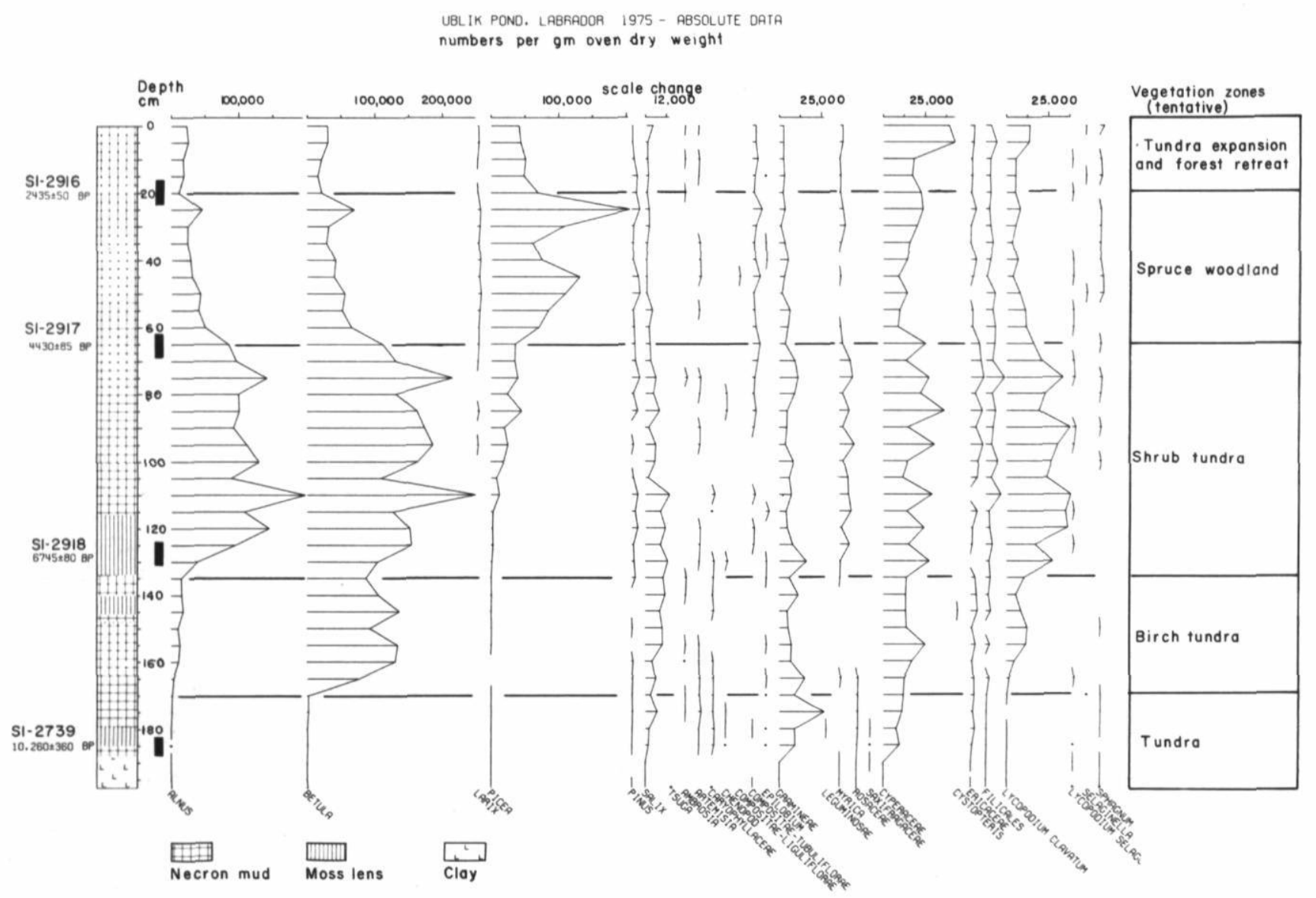

FIGURE 4. Example of a recent pollen diagram: Ublik Pond, near Nain (from SHORT and NICHOLS, 1977).

climate have occurred in the last 6000 to 8000 years, however, has been well substantiated by SHORT and NICHOLS (1977) who argue that apparent absence of such changes from Morrison's pollen diagrams may be explained by the fact that his sites lay in the relatively "climatically complacent" area of the northern Boreal Forest, and his analyses were of the less sensitive "relative percentage" type. Additional support for this conclusion was obtained through a radiocarbon age of $4440 \pm 105$ BP (DIC-883) on a spruce snag presently located above treeline in the Helluva Lake vicinity (Ives, unpubl.). This permits the inference that up to about 4500 years ago treeline had reached a more advanced position than that of today. This in turn relates these initial studies in Labrador-Ungava to the major scheme that NICHOLS (1975) has developed for Keewatin and Mackenzie districts.

Assuming that a tundra period of significant duration occurred so that permafrost could develop in areas currently occupied by occasional small patches of relic permafrost, it must now be shown that climatic conditions prevailing at the time would have been conducive
Exemple d'un diagramme pollinique récent (d'après SHORT et NICHOLS, 1977).

to such deep freezing of the ground. In 1959-1960 meteorological screens were erected along the ridge crest of the Ferriman Mine area west of Schefferville. This was the basis for a comparison between air temperatures in this area, underlain by thick permafrost, and the Schefferville area itself, where no permafrost had been detected and where the vegetation is a mosaic of closed-crown forest and open lichen woodland. The use of gross data, such as mean annual air temperatures, on this rather small scale, is admittedly tentative. Nevertheless, the mean annual air temperatures of the two contrasting sites, windswept tundra and woodland some $250 \mathrm{~m}$ vertically apart, are practically identical. This was based upon a single year's observations, although it appears that Schefferville winters are colder, with the much larger number of temperature inversions, while Ferriman Ridge summers are cooler, in part because of higher altitude and in part because of more frequent ridge-top cloud cover. The Schefferville mean annual air temperature is $-4.6^{\circ} \mathrm{C}$; that of Wabush is $-3.7^{\circ} \mathrm{C}$; Churchill Falls is $-3.2^{\circ} \mathrm{C}$; and Lake Eon is $-2.6^{\circ} \mathrm{C}$. Thus, it would seem reasonable to conclude 
that, under existing climatic conditions, artificial removal of the forest cover, which would produce extensive snow redistribution by wind, would result in widespread aggradation of permafrost to areas far to the south of Schefferville. This is in part corroborated by the current development, and aggradation, of permafrost in iron ore dumps above Schefferville and below local treeline.

Some modifications and exceptions to the general hypothesis must now be discussed. First, areas not covered by Laurentide ice during the maximum of the Last Glaciation should display very thick permafrost, a combination of "modern" permafrost and that developed over a much longer period of Late Cenozoic time. These areas would be confined predominantly to the Labrador coast north of Nain, although it may be speculated that the thick permafrost at Asbestos Hill (BROWN, 1969; TAYLOR and JUDGE, 1979) may also fall into this category. Another area that may have remained ice-free at the maximum of the Last Glaciation is the coastal strip of southeast Labrador (IVES, 1978; VILKS and MUDIE, 1978; Wright, personal communication, 1978). Next, large areas of the peninsula were submerged either by the Holocene marine transgression or fresh water ice-dammed lakes immediately following deglaciation. These areas include especially a wide strip of land between Fort Rupert and Cape Wolstenholme, and much of the basins of the Leaf, Koksoak, George and Whale Rivers. Also included is the area stretching along the northern side of the Laurentide Escarpment from former glacial Lake Barlow-Ojibway to north of present-day Sept-îles.

Finally, in the southwesternmost section of the peninsula, approaching the Laurentide Park, a combination of much earlier deglaciation and vegetational succession (RICHARD, 1977 a, 1977 b) and a generally much warmer present-day and past climate, may have mitigated against preservation of patches of relic permafrost. However, the possibility of future discovery of relic permafrost should by no means be ruled out.

\section{CONCLUSION}

The known present-day distribution of permafrost in Labrador-Ungava, characterized by widespread occurrence beneath windswept treeless areas and scattered patches of relic permafrost below treeline as far south as the Laurentide Escarpment, can be explained in terms of lateglacial/postglacial variations in cover type, rather than by assuming major climatic changes, or inheritance from cold periods (i.e., pre-Wisconsin). This hypothesis is justifiable as a first approximation only, because of the special climatic-topographic-vegetational-ground temperature relationships that characterize the area. In particular it is not intended to imply that "modern" permafrost distribution coincides absolutely with treeline, since treeline itself is frequently an extended ecotone and permafrost is found within a mixed tundra, shrub-tundra, woodland mosaic. The model for postglacial permafrost development presented in this paper is a first step and it is fully expected that deep drilling and thermal exploration will reveal many complexities in the permafrost history that are not recognized here.

\section{ACKNOWLEDGEMENTS}

H. E. (Buzz) Neal, formerly with the Iron Ore Company of Canada, induced me to struggle with the problems of permafrost distribution in the Schefferville area while I was Field Director of the McGill Sub-Arctic Research Station, 1957-1960. This implanted a strong and continuing interest in permafrost and associated environmental problems. The ideas expressed here were barely formulated at that time and since have benefitted greatly from numerous discussions with my colleague, R. J. E. Brown, who also read an earlier version of the text and made many useful suggestions. I also acknowledge the considerable assistance offered by James Gray and two unnamed reviewers to whom I am especially indebted for bringing to my attention the great amount of palynological work being undertaken by Québec researchers. Finally, this paper represents a contribution to INSTAAR's studies of climatic change in the Eastern Arctic and Subarctic supported by U.S. National Science Foundation grant number ATM 7717549.

\section{REFERENCES}

ANDREWS, J. T. (1961): Permafrost in southern LabradorUngava, Can. Geogr., Vol. 5, No. 3, p. 34-35.

ANNERSTEN, L. J. (1964): Background for the Knob Lake Permafrost Studies, J. Brian Bird (Ed), Permafrost Studies in Central Labrador-Ungava, McGill Sub-arctic Research Papers, No. 16, p. 1-32.

BLACK, R. F. (1954) : Permafrost - A review, Bull. Geol. Soc. of Am., Vol. 65, p. 839-856.

BONNLANDER, B. and MAJOR-MAROTHY, G. M. (1964): Permafrost and ground temperature observations, 1957, McGill Sub-arctic Research Paper, 16, p. 33-50.

BROWN, R. J. E. (1960): The distribution of permafrost and its relation to air temperature in Canada and the USSR, Arctic, Vol. 13, No. 3, p. 163-177.

(1965): Permafrost investigations in Saskatchewan and Manitoba, Nat. Res. Coun. Can., Div. Bldg. Res., NRC 8375 , $30 \mathrm{p}$. 
- (1967): Permafrost investigations in British Columbia and Yukon Territory, Nat. Res. Coun. Can., Div. Bldg. Res., NRC 10465, $39 \mathrm{p}$.

(1968): Permafrost investigations in Northern Ontario and Northeastern Manitoba, Nat. Res. Coun. Can., Div. BIdg. Res., NRC 0762, 55 p.

- (1969): Factors influencing discontinuous permafrost in Canada. The Periglacial Environment, Past and Present, T. L. Péwé (ed.), p. 11-53. INQUA, 7th Congress, Alaska, 1965. McGill-Queens Univ. Press, Montreal.

- (1975): Permafrost investigations in Québec and Newfoundland (Labrador), Nat. Res. Coun., Div. Bldg. Res., NRC 14966, 36 p. + app. and ill.

(1979): Permafrost distribution in the southern part of the discontinuous zone in Nouveau-Québec and Labrador. Géogr. phys. Quat., Vol. 33, Nos. 3-4, p.

BRYSON, R. A., WENDLAND, W. M., IVES, J. D. and ANDREWS, J. T. (1969): Radiocarbon isochrones on the disintegration of the Laurentide Ice Sheet, Arctic and Alpine Res., Vol. 1, No. 1, p. 1-14.

CAPLAN, B. (1961): Beating the permafrost at Twin Falls, Eng. Contract Rec., Vol. 74. No. 11, p. 61-63.

BOtTERON, G., GILBERT, C. LOCAT, C. and GRAY, J. T. (1979) : Observations préliminaires sur la répartition du pergélisol dans le bassin de la grande rivière de la Baleine, Géogr. phys. Quat., Vol. 33, Nos. 3-4, p. 253-264.

CLIMAP Project Members (1976): The surface of the ice-age earth, Science, Vol. 191, No. 4232, p. 1131-1137.

DAVIES, R. B., BRADSTREET, T. E., STUCKENRATH, R. Jr. and BORNS, H. W., Jr. (1975): Vegetation and associated environments during the last 14,000 years near Moulton Pond, Maine, Quat. Res., Vol. 5, p. 435-465.

GRAY, J. T. and PILON, J., 1976: Permafrost distribution at Tasiujag (Leaf Basin) on the southwest coast of Ungava Bay, New Québec, Rev. Géogr. Montr., vol. 30, No. 4, p. 367-373.

GRAY, J. T. and BROWN, R. J. E. (1979): Permafrost presence and distribution in the Chic-Chocs Mountains, Gaspésie, Québec, Géogr. phys. Quat., Vol. 33, Nos. 3-4, p. 299-316.

GRAYSON, J. T. (1956): The post-glacial history of vegetation and climate in the Labrador-Quebec region as determined by palynology, Unpub. Ph.D. thesis, Univ. of Michigan, $252 \mathrm{p}$.

HAEBELI, W. (1975) : Untersuchungen zur verbreitung von permafrost zwischen Flüelapass und Piz Grialetsch (Graubunden), Mitteilungen der Versuchsanstalt für Wasserbau, Hydrologie und Glaziologie ETH Zürich, No. 17, 221 p.

(1978): Special aspects of high mountain permafrost methodology and zonation in the Alps, Proc. Third Intern. Permafrost Conf., Nat. Res. Counc. Can., Ottawa, Vol. 1, p. 379-384.

HARE, F. K. (1959) : A photo-reconnaissance survey of LabradorUngava, Geogr. Br., Dept. M.T.S., Ottawa. Memoir 6, 83 p.

IVES, J. D., (1960a) : Permafrost in central Labrador-Ungava, J. Glaciol., Vol. 3, No. 28, p. 789-790. (1960b): The deglaciation of Labrador-Ungava: An outline, Cah. Géogr. Qué., Vol. 4, No. 8, p. 323-343.

$(1960 \mathrm{c})$ : Glaciation and deglaciation of the Helluva Lake area, central Labrador-Ungava, Geogr. Bull., No. 15, p. 4664.

(1961): A pilot project for permafrost investigations in central Labrador-Ungava, Geogr. Br. Dept. M.T.S., Ottawa, Geogr. Paper 28, 22 p. + ill.

(1962): Iron mining in permafrost, central LabradorUngava, Geogr. Bull., Vol. 17, p. 66-77.

(1973): Arctic and alpine geomorphology - A review of current outlooks and notable gaps in knowledge. Third Guelph Symposium on Geomorphology, B. D. Fahey and R. D. Thompson (Eds.) Geol. Abstracts Ltd., Univ of East Anglia, p. 1-10.

- (1974): Permafrost, Chapter 4A in J. D. Ives and R. G. Barry (Eds.) Arctic and Alpine Environments, Methuen, London, p. 157-194.

(1978): The maximum extent of the Laurentide Ice Sheet along the eastern coast of North America during the Last Glaciation, Arctic, Vol. 31, No. 124-53.

IVES, J. D., NICHOLS, H. and SHORT, S. K. (1976): Paleoecology and glacial history of northeastern Nouveau Québec and northern Labrador, Arctic, Vol. 29, No. 1, p. 48-52.

JENNESS, J. L. (1949): Permafrost in Canada, Arctic, Vol. 2, No. 1, p. 13-27.

JORDAN, R. (1975): Pollen diagrams from Hamilton Inlet, central Labrador, and their environmental implications for the Northern Maritime Archaic, Arctic Anthro., Vol. 12, p. 92-116.

LAMB, H. H. and WOODROFFE, A. (1970): Atmospheric circulation during the last Ice Age, Quat. Research, Vol. 1, p. 29-58.

LAWRENCE, D. H. (1929) : Lady Chatterly's Lover, Paris.

McANDREWS, J. H. (1976): Holocene pollen analysis from northern Quebec, Amer. Quat. Assoc., Abstracts of the Fourth Biennial Meeting, Tempa, Arizona, p. 1111.

MCANDREWS, J. H. and SAMSON, G. (1977): Analyse pollinique et implications archéologiques et géomorphologiques, lac de la Hutte Sauvage (Mushuau Nipi), NouveauQuébec, Géogr. phys. Quat., vol. 31, Nos. 1-2, p. 177-183.

MORRISON, A. (1966) : Glacial geomorphology of the Churchill Falls area, Labrador, Unpub. Ph.D. thesis, McGill Univ. Montréal, $376 \mathrm{p}$.

(1970): Pollen diagrams from interior Labrador, Can. Jour. Bot., Vol. 48, p. 1957-1975.

MOTT, R. J. (1977) : Late-Pleistocene and Holocene palynology in southeastern Québec, Géogr. phys. Quat., vol. 31, Nos. 1-2, p. 139-149.

NICHOLS, H. (1975): Palynological and paleoclimatic study of the late Quaternary displacements of the Boreal foresttundra ecotone in Mackenzie and Keewatin, N.W.T., Canada, Univ. of Colorado, Inst. of Arctic and Alpine Research, Occas. Paper 15, $97 \mathrm{p}$. 
NICHOLSON, F. H. (1975): Snow depth mapping from aerial photographs for use in permafrost prediction, Proc. 32nd Eastern Snow Conference, p. 124-136.

(1976): Permafrost thermal amelioration tests near Schefferville, Québec, Can. Jour. Earth Sci., Vol. 13, p. 16941705.

(1979) : Permafrost spatial and temporal variations near Schefferville, Nouveau-Québec, Géogr. phys. Quat., Vol. 33 , Nos. 3-4, p. 265-277.

NIKIFOROFF, C. C. (1928): The perpetually frozen subsoil of Siberia, Soil Science, vol. 26, p. 61-81.

POTZGER, J. E. (1953): Nineteen bogs from southern Québec, Can. J. Bot., Vol. 31, p. 383-401.

PREST, V. K. (1970): Quaternary geology of Canada, in Geology and Economic Minerals of Canada, Geol. Sur. Can. (Econ. Geol. Rept. No. 1), p. 675-764.

RICHARD, P. (1973): Histoire postglaciaire comparée de la végétation dans deux localités au sud de la ville de Québec, Nat. Can., Vol. 100, No. 6, p. 591-603.

(1975a) : Contributions à l'histoire postglaciaire de la végétation dans les Cantons-de-l'Est: étude des sites de Weedon et Albion, Cah. Géogr. Qué., Vol. 19, No. 47, p. 267-284.

- (1975b): Contribution à l'histoire postglaciaire dans la plaine du Saint-Laurent: Lotbinière et Princeville, Rev. Géogr. Montr., Vol. 29, No. 2, p. 95-107.

(1977a): Histoire post-wisconsinienne de la végétation du Québec méridional par l'analyse pollinique, Min. des Terres et Forêts, Québec, 2 tomes, 312 et 141 p. (1977b): Végétation tardiglaciaire au Québec méridional et implications paléoclimatiques, Géogr. phys. Quat., Vol. 31, Nos. 1-2, p. 161-176.

SHORT, S. K. and NICHOLS, H. (1977): Holocene pollen diagrams from subarctic Labrador-Ungava: Vegetational history and climatic change, Arctic and Alpine Res., Vol. 9, No. 3, p. $265-290$.

SUGDEN, D. E. (1977): Reconstruction of the morphology, dynamics, and thermal characteristics of the Laurentide ice sheet at its maximum, Arctic and Alpine Res., Vol. 9, No. 1, p. 21-47.

(1978): Glacial erosion by the Laurentide ice sheet, J. Glaciology, Vol. 20, No. 83, p. 367-391.

TAYLOR, A. and JUDGE, A. (1979): Permafrost studies in Northern Québec, Géogr. phys. Quat., vol. 33, Nos. 3-4, p. $245-251$.

TERASMAE, J. and LASALLE, P. (1968): Notes on late-glacial palynology and geochronology at St. Hilaire, Quebec, Can. J. Earth Sciences, Vol. 5, p. 249-257.

VILKS, G. and MUDIE, P. J. (1978): Early deglaciation of the Labrador shelf, Science, Vol. 202, p. 1181-1183.

WENNER, C. G. (1947): Pollen diagrams from Labrador, Geogr. Ann., Vol. 29, p. 137-373.

WILLIAMS, G., BARRY, R. G. and WASHINGTON, W. M. (1974): Simulation of the atmospheric circulation using NCAR global circulation model with ice age boundary conditions, J. Applied Meteorol., Vol. 13, No. 3, p. 305-317. 